\title{
RELATEDNESS OF STUDENTS' WORK INDUSTRIAL EXPERIENCE TO THE PROFESSIONAL SKILLS AND COMPETENCE DEVELOPMENT IN ENGINEERING CAREER AT NIGERIAN UNIVERSITIES
}

\begin{abstract}
Qualitative occupational training and assessment through acquaintance with the knowledge and insight for transference of concepts and procedure of the fundamental scientific and mathematical skills obtainable in engineering profession produces effective and efficient engineering graduates. Thus, it is a guarantee of effective technical manpower development for the sake of the nation. This is the conceptual basis for this study as it assesses the relevance of workplace and industrial work experience of engineering students to their professional skills training and competence development in engineering disciplines in Nigeria universities. The survey instrument designed for data collection from the participants in the study was an open and closed-ended format questionnaire. It comprises placement category, job experience category, relatedness of placement to the chosen career, relatedness of knowledge/skills in the deployed station in places of attachment and additional gained experience through hands-on incidents during industrial training period. The questionnaire was hand delivered to the participants. Data analysis has been carried out using SPSS version 16.0. Pearson Moment Correlation Coefficient at $95 \%$ confidence intervals were computed to determine the extent of association between the relevance of the knowledge/skills obtained during students' industrial training and the establishments where they were employed for their SIWES to their course of study. P value $<0.05$ was considered statistically significant. The findings has shown that there was positive correlation (' $r$ ' value of 0.375) between the experiences gained in the establishments where students were attached for their industrial training as well as the knowledge and skills acquired in the places of their industrial training. This implies that skills and competence development in engineering career fundamentally enhances students' training in engineering field through hands-on experience involved in industrial training. skills.

Keywords: training, students, engineering career, industrial experience, professional

\section{INTRODUCTION}

Technology advancement and the growing trends in industries demand from engineering graduates some certain fundamental skills in line with their career (Ayob, Osman, Omar, Jamaluddin, Kofli \& Johar 2013). Enhancing concepts and procedures transference ability imbedded in any engineering discipline and work environment entails efficient and effective training processes. Hands-on experience cannot be imparted through lectures (Collins, 2002). It can only be gained through direct activity either from technical practices in workshops or real world confrontation. Practice based on the courses taught to the student during semesters and Student Work Experience Programme (SWEP) is very constrained in terms of time, tools,
\end{abstract}


materials and equipment available in schools. Industrial training gives engineering students a glimpse of what the real-world confrontation is all about. Learning and training opportunities extant in industrial training harmonize the career development engineering students receive in schools and as well establish a collaborative link between the education sectors and the industrial sector (Bullock, Gould, Hejmadi \& Lock, 2009) for effectual manpower development.

The course industrial training also known as Student Industrial Work Experience Scheme (SIWES) among Nigerian engineering students lasts for three (3) and six (6) months during the students' vacation at the end of the $3^{\text {rd }}$ and $1^{\text {st }}$ semesters in the $4^{\text {th }}$ year of the five years study respectively. This is usually the first hands-on off campus academic constructive training for engineering students in the field work of engineering profession. Production of effective engineering graduates who will, in addition to the fundamental scientific and mathematical knowledge of engineering principles and design, be able to demonstrate competent technical skills obtainable in engineering career demands qualitative occupational training and assessment.

Several studies have shown that exposure to both professional and vocational practices in different occupations in a variety of tasks and experiences enhance students' knowledge and understanding; grant them the opportunity to apply the knowledge, skills and attitudes acquired through other course work in the workplace (Rodzalan and Saat, 2012); develop and enhance students' job competency (Alexander, William, Asaah \& Zakari, 2012); make them more informed about their chosen career; and improve employability (Alexander, William, Asaah \& Zakari, 2012; Ballinger \& Lalwani, 2000). It was stated that employability of a student could be marred if practical skills are lacking as their value in the industrial sector is limited. This affirms that industrial training prepares graduates for the world of work much better. Graduates with both theoretical and practical skill have advantages in the selection done in many industrial sectors (Alexander, William, Asaah \& Zakari, 2012).

Industrial training intensively balances with the abstract nature theoretical knowledge proffered with practical experience (Teichler, 1998; Teoh, 2006). The knowledge gained during the industrial training helps build the critical thinking in the training as it is related to what the students were taught or handled with, as it is prevalent in the practical setting situations (Rodzalan \& Saat, 2012). Relating the acquired knowledge to real world challenges not only forms critical thinking ability of the students but also boosts their problem solving ability in the nearest future. Other benefits offered by industrial training include access to job networks; insight development of human relationships and safety aspects involved in the practical application of engineering science in the society (Little \& Harvey, 2006; Wilton, 2012; Oni, 2007). Industrial training is not limited to the development of the trainee's job competence but also plays an important role in enhancing quality of professionals produced in various fields (Omar, Rahman, Kofli, Mat, Darus \& Osman, 2008). Industrial training offers students early acquaintance with the team working for knowledge sharing and close relationship with those in their team (Conti \& Kleiner, 1997). It provides early acquaintance with the practices of engineering profession. It also enhances skills development in the profession (Omar, Rahman, Kofli, Mat, Darus \& Osman, 2008; Alexander, William, Asaah \& Zakari, 2012). Trust and respect for superiors are also built during this period to enhance knowledge transference from employees to trainees (Rodzalan \& Saat, 2012). This shapes the mind of the trainee towards the reality of their chosen profession (Alexander, William, Asaah \& Zakari, 2012). V. Dick, A. Tissington \& G. Hertel (2009) added that individual motivation can be enhanced when trainees are involved. The study also pointed out that older employees in a team serve as sources of reference which motivate the trainee in their career training in team working. This gives the 
educational sector direction to the needs of the industrial sectors and devises ways to improve or adjust the knowledge impartation in the institution (Sutliff, 2000). According to A. Alexander, A. William, A. Asaah \& A. Zakari, 2012 (2012) industrial training helps identify various needs of employers. Through hands-on experience trainees learn work ethics through professional and practical application of skills in the real life situations. Their already acquired skills and knowledge are refined thereby enhancing their efficiency and expertise. Mastering intellectual techniques in one's profession distinguishes colleagues from those who have not taken time to upgrade themselves or utilize this opportunity in the real life situations.

Observations made by A. Afonja, K. Sraku-Lartey \& A. Oni (2005) reveal that there are factors that seriously hamper the vision and mission of industrial training as it relates to professional training of the students. These include inappropriate placement in the place of attachment, deliberate limitation of the hands-on experience that the trainees are made to undergo and poor supervision of the trainees (Afonja, Sraku-Lartey \& Oni, 2005; Kofoworola, 2003). The rightful achievement of the purpose of engineering students' industrial training should emphasize not only students' participation in the program but also relevance of students' work experience to the professional skills and competence development in their chosen career. This formed the conceptual basis for this study.

\section{THE AIM OF THE STUDY}

This study is aimed at assessing the relevance of workplace and industrial work experience of engineering students and their professional skills training and competence development in engineering disciplines at Nigerian universities.

\section{THEORETICAL FRAMEWORK AND RESEARCH METHODS}

The participants in this study were engineering students in Nigeria universities. The consent for participation was obtained from the participants by the researcher via personal contacts with respondents before the commencement of their industrial training. 129 participants who turned up to the earlier made proposal to participate in the study at the end of their industrial training were considered $100 \%$ sample for the study. The survey instrument designed for data collection from the respondents in the study was an open and closed-ended format questionnaire. This comprises placement category, job experience category, relatedness of placement to the chosen career, relatedness of knowledge/skills in the deployed station in places of attachment and additional gained experience through hands-on incidents during industrial training period. The questionnaire was hand delivered to the participants. Data analysis was carried out using SPSS version 16.0. Pearson Moment Correlation Coefficient at $95 \%$ confidence. Intervals were computed to determine the extent of association between the relevance of the skills/ knowledge obtained during students' industrial training and the establishments where they were employed for their SIWES to their course of study. $\mathrm{P}$ value $<0.05$ was considered statistically significant. The results obtained in this study were presented in the chart and table.

\section{RESULTS}

Engineering is extremely broad and encompasses a range of more specialized fields of engineering, each with a more specific emphasis on particular areas of technology and types of application. Engineering students during their undergraduate years experience intellectual growth through a wide range of exposure relevant to their career. Theoretical knowledge and hands-on practice in various specialized fields of engineering usually prepare students for the world of work. The fundamental skills engineering graduates possess pledges employability. Depending on relevance and the level of mastery of these developed fundamental skills in one's career, blending and teaming with existing staff in 
any organization would seem not to be a challenge. Acquiring necessary and relevant experience to one's profession will lead to rise in improved technical workforce and human capital base of the nation. Places where students undertake their industrial attachments, as presented in this study, vary across different aspects of engineering practices with majority in construction sites 30 (23.3), factories 21 (16.3), technical workshops 33 (25.6), laboratories 5 (3.9), schools 5 (3.9), servicing companies $1(0.8)$ and other vast specified/specialized areas in engineering profession reported by the participants 29 (22.5).

Engineering work environment addresses more complex and ambiguous problems than in school. The whole essence of work placement will not be realized if there is no adjunct or augmented experience for the students' industrial training and career. $83.0 \%$ of the participants gained additional experience through working with equipment, using methods and techniques not available in school. To $10.1 \%$ of the participants it was like a continuation or rather repetition, while $5.4 \%$ of the participants could not fix their stand (Fig. 1).

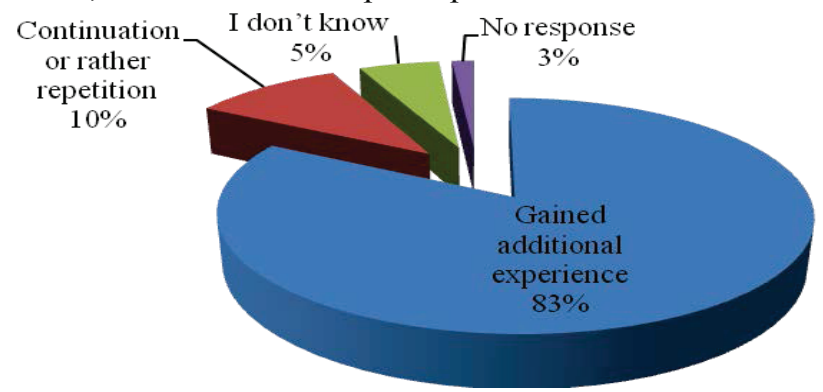

Fig. 1. Adjunct career development experience from SIWES

Being knowledgeable and versatile in the application skills and competencies to perform a defined job or work grants an individual who has been exposed to both the theoretical foundation and hands-on experience involved in engineering profession an opportunity to perform better in the chosen profession. For the period of 6-months during which students were expected to actively participate and benefit from the industrial training, 33 students, representing $80.5 \%$ of the participants, completed their industrial training. According to B. Little and L. Harvey (2006) the duration of work placement must be determined. To some extent the range and scope of activities that students can undertake as well as the opportunities for the development of knowledge, skills and attributes to what might be afforded at the work placement establishment. The complement of an industrial training or work placement period is a positive benefit to both graduates and employers, particularly in an era that stresses economic contribution of higher education through developing graduates' employability (Ayob, Osman, Omar, Jamaluddin, Kofli \& Johar, 2013). Industrial training in engineering is very important as it gives an insight on how the industry operates, and provides the necessary engineering career exposure (Ayob, Osman, Omar, Jamaluddin, Kofli \& Johar, 2013). The experience the students are privileged to have depends on the operation, type and nature of work going on in the place of industrial training at the time of attachment. The places of attachment, represented in this study, cover wide range of various areas of specialties in engineering profession with predominance being given to job experiences in maintenance (44.2\%), manufacture $(10.1 \%)$, assembly 
(5.4\%), troubleshooting (12.4\%), design and drafting (2.3\%), and other vast specified/specialized areas reported by the participants (24\%) (Table 1). One important aspect in obtaining a relevant industrial training is the match between the students' enrollment degree program and the type of company providing the training. Relevance of the place of attachment to the chosen career was assessed and it was found that the degree of relatedness of the participants to their profession was highly (73.6\%) and averagely (20.9\%) relevant to participants respectively (Table 1). There was no participant whose area of attachment was not relevant to the chosen field.

Table 1

Work experience establishment's characteristics and its relevance to engineering career development

\begin{tabular}{|c|c|c|}
\hline $\begin{array}{c}\text { Industrial training } \\
\text { and establishments' characteristics }\end{array}$ & Characteristics & N (\%) \\
\hline \multirow{7}{*}{ SIWES establishment WORK } & Maintenance & $57(44.2)$ \\
\hline & Manufacture & $13(10.1)$ \\
\hline & Assembly & $7(5.4)$ \\
\hline & Troubleshooting & $16(12.4)$ \\
\hline & Other specify & $31(24.0)$ \\
\hline & Design & $3(2.3)$ \\
\hline & Total & $127(98.4)$ \\
\hline \multirow[t]{5}{*}{$\begin{array}{l}\text { SIWES establishment related } \\
\text { to the course of study }\end{array}$} & Slightly relevant & $5(3.9)$ \\
\hline & Undecided & $1(0.8)$ \\
\hline & Averagely relevant & $27(20.9)$ \\
\hline & Highly relevant & $95(73.6)$ \\
\hline & Total & $128(99.2)$ \\
\hline \multirow[t]{5}{*}{$\begin{array}{l}\text { Knowledge/skills relevant } \\
\text { at SIWES establishment }\end{array}$} & Slightly relevant & $4(3.1)$ \\
\hline & Undecided & $1(0.8)$ \\
\hline & Averagely relevant & $26(20.2)$ \\
\hline & Highly relevant & $97(75.2)$ \\
\hline & Total & $128(99.2)$ \\
\hline
\end{tabular}

A. Ayob, A. Osman, Z. Omar, N. Jamaluddin, T. Kofli \& S. Johar, 2013 (2013) observed that experience and training students gained in places of attachment might not be related to the students' career path irrespective of the perceived nature of activities in the place of attachment. The department or the section which the student is deployed to is very important in work placement. Mis-deployment or intentional deployment of the trainee to a section different from the trainee's career during work placement may offer the student the opportunity to learn and handle different tasks in the deployed section but leaves the trainee deficient in the basic knowledge pertinent in his/her area of study (Ayob, Osman, Omar, Jamaluddin, Kofli \& Johar, 2013). Experience or training that the students partake beyond the scope of their job specification will not provide the relevant engineering experience which will be required by the student to prepare him/her for a career in engineering profession. The knowledge and skills gained in the place of attachment were found to be highly relevant (75.2\%) and averagely relevant (20.2\%) among the participants (Table 1).

Correlation analysis was used to determine the extent of association between the relevance of the skills/knowledge obtained during students' industrial training and the 
establishments where students were employed for their SIWES in the course of study. According to M. Sabellah (2010) the correlation between two variables may either be positive, negative or zero (independent of each other) depending on the relationship between the variables. This ranges from a value of +1.00 for absolutely positive correlation to a value of -1.00 for absolutely negative correlation. In this study a correlation ' $r$ ' value of 0.375 was obtained, which was a positive correlation. This showed that the skills/ knowledge obtained during students' industrial training are relevant to their chosen career. This is a result of undertaking and obtaining the industrial training in an establishment relevant to their field of study which, in its turn, enhances their professional skills and competency development in engineering career.

\section{CONCLUSIONS}

Exposure to real-world confrontation through hands-on experience prevalent in industrial training aids equip the students with the skills and knowledge, which engineering students are required to have as professionals in different areas of expertise. Relatedness of students' work experience to actualization of their professional skills and competence in engineering career has been proved in this study. Nigerian engineering students in this study indicated that there is a positive correlation between the establishments where students were attached for their industrial training and the knowledge/skills acquired in the deployed places of attachment. This implies that students undertaking and obtaining industrial training in an establishment relevant to their field of study enhance their professional skills and competency development in engineering career.

The growing trend and concern for the production engineering professionals who can effectively and efficiently transfer the concepts and procedures of the fundamental scientific and mathematical skill obtainable in engineering profession into the work environment demand the acquired professional skills and developed competence of the trainees to be subjected to further investigation and critical appraisal so as to ascertain and validate the dimension and degree of professional proficiency attained from industrial work exposure.

\section{REFERENCES}

1. Afonja, A., Sraku-Lartey, K., \& Oni, A. (2005). Engineering education for industrial development: case studies of Nigeria, Ghana and Zimbabwe. ATPS Working Paper No. 42. Nairobi, Kenya: The African Technology Policy.

2. Alexander, A. William, A., Asaah, A. \& Zakari, A. (2012). The impact of students' industrial training on their on their on their employability status after graduation: evidence from Kumasi in Ghana. International journal of advances in management and economics, 1 (4), 108-114.

3. Ayob, A., Osman, A., Omar, Z., Jamaluddin, N., Kofli, T., \& Johar, S. (2013). Industrial training as gateway to engineering career: experience sharing. Procedia-social and behavioral sciences, 102, 48-54.

4. Ballinger, C., \& Lalwani, S. (2000). The role of internships in marine policy and integrated coastal management higher education. Ocean \& coastal management, 43 (4-5), 409-426.

5. Bullock, K., Gould, V., Hejmadi, M., \& Lock, G. (2009). Work placement experience: Should I stay or should I go? Higher education research \& development, 28 (5), 481-494.

6. Collins, B. (2002). Gateway to the real world, industrial training: Dilemmas and problems. Tourism management, 23 (1), 93-96. 
7. Conti, B., \& Kleiner, H. (1997). How to increase teamwork in organizations. Training for quality, 5 (1), 26-29.

8. Dick, V., Tissington, A., \& Hertel, G. (2009). Do many hands make light work?: How to overcome social loafing and gain motivation in work teams. European business review, 21 (3), 233-245.

9. Kofoworola, F. (2003). Engineering education in Nigeria: present learning systems and challenges for the future. Australasian J. Eng. Edu, 1, 2-7.

10. Little, B., \& Harvey, L. (2006). Learning through work placements and beyond. A Report for the Higher Education Careers Services Unit and the Higher Education Academy's Work Placements Organisation Forum. Higher Education Careers Service Unit.

11. Omar, Z., Rahman, A., Kofli, T., Mat, K., Darus, Z., \& Osman, A. (2008). Assessment of engineering students' perception after industrial training placement. The 4th WSEAS/IASME international conference on educational technologies (EDUTE '08).

12. Oni, S. (2007). Globalization and its implications for vocational education in Nigeria. Essays in Education, 21 (1), 30-34.

13. Rodzalan, A., \& Saat, M. (2012). The effects of industrial training on students' generic skills development. Procedia-social and behavioral sciences, 56, 357-368.

14. Sabellah, M. (2010). The relationship between attitude and academic performance in chemistry among secondary school students. A case of central Kisii district, Kenya. Unpublished Masteral thesis, Moi University Eldoret, Kenya.

15. Sutliff, K. (2000). Integrating academics and industry: a challenge for both sides. ACM journal of computer documentation (JCD), 24 (1), 33-38.

16. Teichler, U. (1998). The requirements of the world of Work. Proceedings of the World Conference on Higher Education - Higher Education in the Twenty-first Century: Vision and Action 5. UNESCO.

17. Teoh, S. (2006). Industry Explores Internship Issues. The star online, 4, 12-16.

18. Wilton, N. (2012). The impact of work placements on skills development and career outcomes for business and management graduates. Studies in higher education, 37 (5), $603-620$. 